\title{
FIRST REPORT ON THE ASSOCIATION OF A BEGOMOVIRUS WITH CHRYSANTHEMUM INDICUM EXHIBITING YELLOWING OF LEAF VEIN DISEASE CHARACTERIZED BY MOLECULAR STUDIES
}

\section{Short communication}

\author{
Avinash MARWAL ${ }^{\#}$, Anurag Kumar SAHU, Rajarshi Kumar GAUR* \\ Department of Science, Faculty of Arts, Science and Commerce, \\ Mody University of Science and Technology, Lakshmangarh, Sikar - 332311, Rajasthan, India
}

Received: August 2, 2013; Accepted: December 11, 2013

\begin{abstract}
Infected leaf samples of an ornamental plant Chrysanthemum indicum showing yellowing of leaf veins were collected from gardens of New Delhi (India). An expected PCR product of size $\sim 500 \mathrm{bp}$ was amplified from total DNA extracts of symptomatic leaf samples with universal primers on the gene of coat protein region of begomovirus DNA-A component. The presence of begomoviruses was also confirmed by Southern blot analysis using control cloned DNA-A probe of Cotton leaf curl virus. Sequence analysis of the virus infecting Chrysanthemum indicum showed $99 \%$ nucleotide sequence identity with Clerodendron yellow mosaic virus (EF408037).
\end{abstract}

Key words: Chrysanthemum indicum plants, begomovirus, PCR, sequencing, Southern blot

\section{INTRODUCTION}

Geminiviridae is a large family of plant viruses with circular, single-stranded DNA (ssDNA) genomes packaged within geminate particles (Cui et al. 2004; Moffat et al. 1999). According to their genome organization and biological properties, the family Geminiviridae is divided into four genera: Mastrevirus, Curtovirus, Topocuvirus and Begomovirus (Fauquet et al. 2003). Over the past few decades, there has been more interest in geminiviruses, especially begomoviruses, as many of the diseases they cause have now reached epidemic character (Brown \& Czosnek 2002).

Ornamental plants serve as alternative hosts for begomoviruses in gardens and may allow the transmission of begomovirus to other horticultural crops and medicinal plants, thus enhancing the host range of these viruses in different regions of India (Marwal et al. 2013a). The vector is the whitefly (Bemisia tabaci) that causes begomoviral infections in ornamentals, crops and weeds. Therefore, increasing knowledge about its epidemiology, sequence diversity and biodiversity is highly important for implementing preventative strategies.

In the present report, we identified a begomovirus associated with a disease of ornamental plant Chrysanthemum indicum, which is a flowering plant within the Asteraceae family. It is a perennial, aromatic, medicinal plant used in the traditional folk medicine in Asia and Europe, against nephritis, women's diseases and in the treatment of neurological problems and headache (Chang et al. 2010). It was also found to have anti-microbial, antioxidant and anti-inflammatory properties (Park et al. 2012).

\section{MATERIALS AND METHODS}

\section{Origin of plants}

Chrysanthemum indicum is native to Asia and northeastern Europe. Most species originate from East Asia and the centre of diversity is in China. A survey of different gardens was made during 
2010-2011. Fourteen Chrysanthemum indicum plants were found with leaf yellow vein disease, which are symptoms typical to begomovirus infection. To investigate the potential begomoviral infection, all the 14 symptomatic Chrysanthemum indicum as well as asymptomatic leaf samples were collected from the same garden in New Delhi.

\section{Extraction of total DNA}

The leaf samples were cleaned, cut, rolled in a piece of tissue paper and stored at $-20^{\circ} \mathrm{C}$ until DNA isolation. Total DNA was extracted from leaves of infected as well as healthy plants using the cetyltrimethylammonium bromide (CTAB) method (Manen et al. 2005). Samples of the total DNA product were analysed by electrophoresis on a 1 or $2 \%$ agarose gel and the concentration was determined by using Nanodrop (Thermo Scientific).

\section{Identification of begomovirus components by PCR}

PCR was performed using a pair of degenerate primers specific to the coat protein region of begomovirus. The forward primer sequence was GGRTTDGARGCATGHGTACATG (AC 1048) and the reverse primer sequence was GCCYATRTAYAGRAAGCCMAG (AV 494) (Marwal et al. 2013b). A final volume of $50 \mu 1$ PCR mixture contained: $100 \mathrm{ng}$ DNA template, $5 \mu 110 \times$ PCR buffer (10 mmol; Tris-HCl, pH 8.8; $50 \mathrm{mmol} \mathrm{KCl}$ ); $2.5 \mathrm{mmol} \mathrm{MgCl}_{2}, 200 \mu \mathrm{mol}$ of each dNTPs, 2 units of Taq DNA Polymerase (Fermentas, India), $0.2 \mu \mathrm{mol}$ of each primer and nuclease free water.

The PCR thermal profile was pre-PCR denaturation at $94{ }^{\circ} \mathrm{C}$ for $120 \mathrm{~s}$ followed by 35 cycles of denaturing at $94{ }^{\circ} \mathrm{C}$ for $45 \mathrm{~s}$, annealing at $55{ }^{\circ} \mathrm{C}$ for $45 \mathrm{~s}$ and extension at $72{ }^{\circ} \mathrm{C}$ for $45 \mathrm{~s}$, and a final extension at $72{ }^{\circ} \mathrm{C}$ for $5 \mathrm{~min}$ (Marwal et al. 2012).

For the detection of any DNA-B component in diseased plant, primer pair PCRc1 and PBLlv2040 was used (Rojas et al. 1993; Bela-ong et al. 2007), having the same PCR condition and reaction as used in the case of begomovirus DNA-A. To test whether a DNA satellite molecule was associated with begomovirus, a universal primer pair specific for alpha-satellite and beta-satellite (Briddon et al. 2002; Bull et al. 2003) was also used to amplify the putative DNA. The concentration of PCR reaction reagents for alpha-satellite and beta-satellite was the same as for DNA-A, mentioned above in the manuscript, whereas the PCR thermal profile was prePCR by denaturation at $94{ }^{\circ} \mathrm{C}$ for $120 \mathrm{~s}$ followed by 35 cycles of denaturing at $94{ }^{\circ} \mathrm{C}$ for $60 \mathrm{~s}$, annealing at $68{ }^{\circ} \mathrm{C}$ for $60 \mathrm{~s}$ and extension at $72{ }^{\circ} \mathrm{C}$ for $60 \mathrm{~s}$, and a final extension at $72{ }^{\circ} \mathrm{C}$ for $5 \mathrm{~min}$.

\section{Cloning, sequencing, Southern hybridization}

The amplified PCR product was purified and cloned into Promega pGEMT vector system as per the manufacturer's instruction. The clones were sequenced and the details were submitted to National Center for Biotechnology Information (NCBI). A phylogenetic tree was generated with the MEGA 4.0 software by using the neighbour-joining method with 1000 bootstrap replications. For final confirmation of begomovirus infectivity, Southern hybridization was performed according to the method of Kon et al. (2003). Cloned DNA-A of Cotton leaf curl virus was used to develop the control radiolabeled probes as a general probe for begomoviruses.

\section{Methodology of biotest}

For conducting biotest, mechanical and seed transmission studies were carried out. In case of mechanical transmission, infected Chrysanthemum indicum leaves were macerated in a pestle and mortar by adding ice cold $0.05 \mathrm{M}$ phosphate buffer, $\mathrm{pH} 7.5$ containing $1 \%$ of 2-mercaptoethanol. The resultant pulp was inoculated into 15 one-week-old seedlings of Chrysanthemum indicum by the unidirectional rubbing of forefinger dipped in inoculum. The plants were maintained in the separate compartment of the glasshouse for symptom production.

In seed transmission biotest, matured seeds were collected from infected Chrysanthemum indicum and non-symptomatic healthy plants. The seeds were treated with $2 \%(\mathrm{v} / \mathrm{v})$ sodium hypochlorite for $3 \mathrm{~min}$ and rinsed with water several times. Two sets of 15 seeds, each from healthy and diseased plants, were sown in soil and kept in a glasshouse for four weeks for the development of symptoms.

\section{Koch's postulate}

Moreover, in order to confirm the Koch's postulate for the virus and assess the infectivity and symptoms of phenotype of the variants, an infec- 
tious clone of virus variants was constructed and inoculated into Nicotiana benthamiana. The presence of virus in the seedlings was confirmed by PCR.

\section{RESULTS}

During the survey, begomovirus symptoms (yellow vein disease) were found on 20-30\% of Chrysanthemum indicum plants growing in the gardens of New Delhi, India (Fig. 1). An expected PCR product from coat protein gene primers $(\sim 500 \mathrm{bp})$ was obtained, cloned suitably into pGEM-T vector, sequenced, and submitted to NCBI database under accession number JN998441. All the screened 14 samples contained the same virus from the genus begomovirus. The symptoms were the same, that is, yellowing of leaf veins in all the infected plants. We have not found any DNA-B, or any satellite molecules.

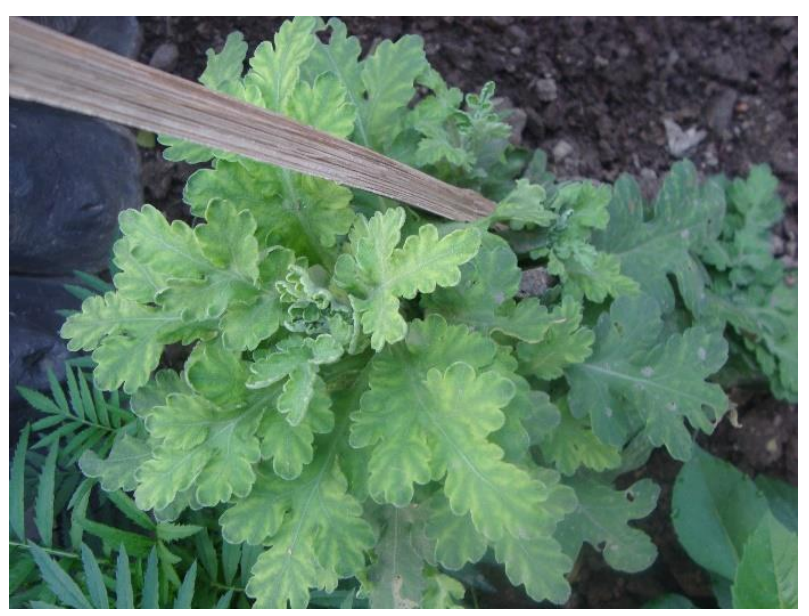

Fig. 1. Symptoms of yellowing of leaf veins on an ornamental plant Chrysanthemum indicum from which the begomovirus was isolated and characterized

Sequence analysis was carried out using BLAST, which revealed that the isolated begomovirus (JN998441) infecting Chrysanthemum indicum showed $99 \%$ sequence identity with Clerodendron yellow mosaic virus (EF408037) and Clerodendron golden mosaic China virus (FN645907). Furthermore, the begomovirus showed lowest sequence identity of $81 \%$, with $T o$ mato leaf curl Pakistan virus (FM164938), Cotton leaf curl Burewala virus (FR750324) and Cotton leaf curl Shadadpur virus (FN552005) being reported from Pakistan.

The begomovirus sequenced have a putative conserved domain of the Geminiviridae family which encodes for coat protein of 154 amino acids having a molecular weight of $18.08 \mathrm{kDa}$ (protein id = "AEY68274.1"). The ORF is designated as AV1, which resides on the positive sense strand of 1 st frame, having nucleotide coordinates in which the start codon begins at position 1 and the stop codon at 461. Even with protein alignments, the begomovirus isolated from Chrysanthemum indicum showed highest amino acid sequence identities of 98\% with Clerodendron yellow mosaic virus (EF408037) reported from India and Clerodendron yellow mosaic virus (HE863667) reported from neighbouring country Pakistan.

Phylogenetic analysis based on the coat protein sequence of begomovirus and other selected sequences indicates that the isolate clusters with the isolates of Clerodendron yellow mosaic virus (EF408037) and Clerodendron golden mosaic China virus (FN645907), which were reported from India. The positive PCR reaction showed the presence of begomovirus, which was further confirmed by Southern blot hybridization using Cotton leaf curl virus as a general and control probe for begomoviruses. All 14 samples from symptomatic plants hybridized with the probe, whereas samples extracted from non-symptomatic plants did not show positive results.

Biotest studies revealed that all the 15 mechanically inoculated seedlings at two-leaf stage showed similar symptoms as those observed on the field-infected plants, whereas the seed transmission biotest studies showed that the virus is not seed borne in nature. The construct developed to test for Koch's postulates caused typical yellow vein symptoms when inoculated into $N$. benthamiana. For each experiment, $20 \mathrm{~N}$. benthamiana plants grown on insect-free greenhouse were taken. This resulted in the development of the same kind of symptoms as observed in Chrysanthemum indicum. The authenticity of infectivity assay was confirmed by using begomovirus coat protein gene primers in PCR. 


\section{DISCUSSION}

There are reports of begomovirus infection in ornamental plants worldwide (He et al. 2009; Ilyas et al. 2013). With regard to the Indian context, numerous reports on begomovirus infection in weeds and crops are available (Chatterjee et al. 2007; Das et al. 2008; Ghosh et al. 2007; Jyothsna et al. 2011; Khan et al. 2002) but there is much less information regarding begomovirus infections in ornamental plants (Marwal et al. 2013b). This is because ornamentals are sometimes neglected or are not taken into consideration while carrying out survey and begomovirus studies. We had found Chrysanthemum indicum plants with symptoms of leaf yellow vein disease typical to begomovirus infection; amplified and sequenced fragments of begomovirus coat protein gene, which showed the same level of nucleotide identity with Clerodendron yellow mosaic virus and Clerodendron golden mosaic China virus. However, Clerodendron yellow mosaic virus and Clerodendron golden mosaic China virus have not been approved as species. Therefore, based on the infected host, observed symptoms and place of collected samples, we propose to this isolate name Chrysanthemum indicum yellow vein Delhi virus.

Thus, this identification represents the possibility of a serious threat to other economically important ornamental and horticulture crop plants. There is a need for a more comprehensive study, which will be focused on the sequencing of the complete genome of the virus and recombination analysis. This can throw light on its origin and can be used to identify possible further begomovirus infections in the country in order to assess their contribution in losses and to develop tools applicable in control strategies. Moreover, advanced molecular techniques such as RNAi will be used for the development of transgenic plant resistance to begomovirus. This will form the basis of our future investigations.

\section{CONCLUSION}

The positive results obtained from molecular and biotest studies confirmed the presence of begomovirus in Chrysanthemum indicum named
Chrysanthemum indicum yellow vein Delhi virus. Results obtained above reveal that the virus is not seed borne in nature but is vector borne. Information will be effectively applied for disease management, crop protection and development of quarantine strategies at the state and national level in India. Moreover, the possible association of a begomovirus with Chrysanthemum indicum had not been investigated previously. Therefore, to the best of our knowledge, this is the first report on begomovirus associated with yellow vein disease of an ornamental plant Chrysanthemum indicum.

\section{Acknowledgements}

The authors would like to thank the Department of Biotechnology (DBT project No. BT/PR13129/GBD/ 27/197/2009) and Department of Science and Technology (DST project No. SR/FT/LS-042/2009), India, for their financial support.

\section{REFERENCES}

Bela-ong D.B., Bajet N.B. 2007. Molecular detection of whitefly-transmissible geminiviruses (genus $\mathrm{Be}$ gomovirus, family Geminiviridae) in the Philippines. Philipp. J. Sci. 136: 87-101.

Briddon R.W., Bull S.E., Mansoor S., Amin I., Markham P.G. 2002. Universal primers for the PCR-mediated amplification of DNA $\beta$. A molecule associated with some monopartite begomoviruses. Mol. Biotech. 20: 315-318. DOI: 10.1385/MB:20:3:315.

Brown J.K., Czosnek H. 2002. Whitefly transmission of plant viruses. Adv. Bot. Res. 36: 65-100. DOI: 10.1016/S0065-2296(02)36059-2.

Bull S.E., Briddon R.W., Markham P.G. 2003. Universal primers for the PCR-mediated amplification of DNA 1: a satellite-like molecule associated with begomovirus-DNA $\beta$ complexes. Mol. Biotech. 23: 83-86.

Chang K., Choi E.M., Kim G.H. 2010. Chemical Constituents of Chrysanthemum indicum L. flower oil and effect on osteoblastic MC3T3-E1 cells. Food Sci. Biotechnol. 19: 815-819. DOI: 10.1007/s10068010-0114-y.

Chatterjee A., Roy A., Ghosh S.K. 2007. First record of a begomovirus associated with yellow vein mosaic disease of Urena lobata in India. Australas. Plant Dis. Notes 2: 27-28. 
Cui X., Tao X., Xie Y., Fauquet C.M., Zhou X. 2004. A DNA $\beta$ associated with Tomato yellow leaf curl China virus is required for symptom induction. J. Virol. 78: 13966-13974. DOI: 10.1128/JVI.78.24.1396613974.2004.

Das S., Ghosh R., Paul S., Roy A., Ghosh S.K. 2008. Complete nucleotide sequence of a monopartite begomovirus associated with yellow vein mosaic disease of mesta from north India. Arch. Virol. 153: 1791-1796. DOI: 10.1007/s00705-008-0181-z.

Fauquet C.M., Bisaro D.M., Briddon R.W., Brown J.K., Harrison B.D. 2003. Virology division news: Revision of taxonomic criteria for species demarcation in the family Geminiviridae and an updated list of begomovirus species. Arch. Virol. 148: 405-421. DOI: 10.1007/s00705-002-0957-5.

Ghosh R., Paul S., Roy A., Mir J.I., Ghosh S.K., Srivastava R.K., Yadav U.S. 2007. Occurrence of begomovirus associated with yellow vein mosaic disease of kenaf (Hibiscus cannabinus) in northern India. Plant Health Progress. DOI: 10.1094/PHP2007-0508-01-RS.

He Z.F., Mao M.J., Yu H., Li H.P., Chen X. 2009. Molecular characterization of a distinct begomovirus infecting Allamanda cathartica in Guangdong, China. Arch. Virol. 54: 1199-202. DOI: 10.1007/s00705-009-0445-2.

Ilyas M., Nawaz K., Shafiq M., Haider M.S., Shahid A.A. 2013. Complete nucleotide sequences of two begomoviruses infecting Madagascar periwinkle (Catharanthus roseus) from Pakistan. Arch. Virol. 158: 505-510. DOI: 10.1007/s00705-012-1498-1.

Jyothsna P., Rawat R., Malathi V.G. 2011. Molecular characterization of a new begomovirus infecting leguminous weed Rhynchosia minima in India. Virus Genes 42: 407-414. DOI: 10.1007/s11262-0110580-1.

Khan J.A., Siddiqui M.K., Singh B.P. 2002. The natural occurrence of a begomovirus in sunn hemp (Crotalaria juncea) in India. Plant Pathol. 51: 398. DOI: 10.1046/j.1365-3059.2002.00714.x.
Kon T., Dolores L.M., Bajet N.B., Hase S., Takahashi H., Ikegami M. 2003. Molecular characterization of a strain of Squash leaf curl China virus from the Philippines. J Phytopathol. 151: 535-539. DOI: 10.1046/j.1439-0434.2003.00764.x.

Manen J.F., Sinitsyna O., Aeschbach L., Markov A.V., Sinitsyn A. 2005. A fully automatable enzymatic method for DNA extraction from plant tissues. BMC Plant Biol. 5: 3-23. DOI: 10.1186/14712229-5-23.

Marwal A., Sahu A., Prajapat R., Gaur R.K. 2012. First report of association of begomovirus with the leaf curl disease of a common weed, Datura inoxia. Indian J. Virol. 23: 3-84. DOI: 10.1007/s13337-0120064-5.

Marwal A., Sahu A., Prajapat R., Gaur R.K. 2013a. First report of Begomovirus infecting two ornamental plants: Jasminum sambac and Millingtonia hortensis. Indian Phytopathol. 66:115-116.

Marwal A., Sahu A., Sharma P., Gaur R.K. 2013b. Molecular Characterizations of Two begomoviruses Infecting Vinca rosea and Raphanus sativus in India. Virologica Sinica 28: 53-56. DOI: 10.1007/s12250-013-3275-z.

Moffat A.S. 1999. Geminiviruses emerge as serious crop threat. Science 286: 1835. DOI: $10.1126 /$ science.286.5446.1835.

Park S., Lee J.B., Kang S. 2012. Topical application of Chrysanthemum indicum L. attenuates the development of atopic dermatitis-like skin lesions by suppressing serum IgE levels, IFN- $\gamma$, and IL-4 in $\mathrm{Nc} / \mathrm{NgaMice}$. Evidence-Based Complementary and Alternative Medicine. Article ID 821967, 8 pp. DOI: $10.1155 / 2012 / 821967$.

Rojas M.R., Gilbertson R.L., Russell D.R., Maxwell D.P. 1993. Use of degenerate primers in the polymerase chain reaction to detect whitefly-transmitted geminiviruses. Plant Dis. 77: 340-347. DOI: 10.1094/PD-77-0340. 